\title{
Accelerated Decay of Glucose 6-phosphate Dehydrogenase Activity in Chronic Granulomatous Disease
}

\author{
Joseph A.Bellanti ${ }^{[29]}$, Brigitta E. Cantz and Robert J. Schlegel \\ Departments of Pediatrics, Georgetown University School of Medicine, Washington, DC, \\ and Stanford University School of Medicine, Palo Alto, California, USA
}

\begin{abstract}
Extract
Glucose 6-phosphate dehydrogenase (EC. 1.1.1.49) (Glc-6-PD) activity was measured in the leukocytes and red cells of three patients with the classic form of chronic granulomatous disease (GGD) and in controls. Leukocyte homogenates from all three children revealed a decreased GIc-6-PD activity. The activities in both white cells and red cells, measured at timed intervals under conditions of storage at $0^{\circ}$ or heating at $38^{\circ}$ revealed a more rapid rate of decay in cells of patients than that seen in cells of control subjects. Studies measuring the activities of Glc-6-PD in the presence of $10 \mu \mathrm{m}$ NADP, or $14 \mathrm{~mm}$ 2-mercaptoethanol, or both, disclosed a stabilizing effect with these reagents.

Measure ment of activity of another NADP-dependent enzyme, 6-phosphogluconic dehydrogenase (EC. 1.1.1.43) (6-PGD), in leukocytes were within normal limits. A correlation coefficient of 0.86 $(P<0.01)$ was found between Glc-6-PD activity and the quantitative nitroblue tetrazolium (NBT) test used to diagnose GGD.
\end{abstract}

\section{Speculation}

An increased rate of decay in activity of glucose 6-phosphate dehydrogenase was detected in the leukocytes and red cells of patients with one form of chronic granulomatous disease. The finding of a functional abnormality in an X-linked enzyme is consonant with the known X-linked recessive mode of transmission of this form of the entity. The metabolic derangement involving leukocyte Glc-6-PD activity may provide a basis for the study of other abnormalities of the leukocyte, the socalled neutrophil dysfunction syndrome [7].

\section{Introduction}

Chronic or fatal granulomatous disease (CGD) was originally described as an X-linked recessive disorder affecting children and manifested by recurrent infections with organisms of low virulence $[6,13,14]$. Histopathologic changes in affected organs consist of granulomatous infiltrations containing plasma cells, lymphocytes, and macrophages. The leukocytes of affected patients can ingest bacteria but are apparently unable to digest them [17].

A metabolic basis for the defect is suggested by the inability of phagocytosing leukocytes to develop the characteristic increase of respiration, hexose monophosphate shunt (HMP) activity and hydrogen peroxide formation occurring in normal leukocytes during phagocytosis $[2,10]$. A simple diagnostic test is based on the inability of leukocytes from affected patients 
to reduce the oxidized form of nitroblue tetrazolium dye (NBT) during phagocytosis [2].

It has been suggested [1] that the inherited defect might be due to diminished activity of an enzyme, $\mathrm{NADH}$ oxidase, which indirectly promotes increased HMP activity during phagocytosis via an NADPHlinked lactate dehydrogenase. Yet the NAD-NADH coenzyme system does not appear to be directly related to the pentose phosphate pathway. In species such as the rat, lacking NADPH-linked lactate dehydrogenase in polymorphonuclear leukocytes, such a mechanism cannot account for the augmented oxidation seen during phagocytosis [19]. Therefore, we decided to search further for the molecular basis of GGD. It will be shown that an abnormally rapid rate of decay of glucose 6-phosphate dehydrogenase (Glc-6-PD) activity occurs in the leukocytes and red cells of patients with GGD.

\section{Materials and Methods}

Three children with typical findings of CGD were studied at Walter Reed General Hospital and Georgetown University Hospital (table I). All subjects tested were white males. Age-adjusted and adult controls were also studied for comparison [26].

Methods for the preparation of a relatively rich suspension of granulocytes were with slight modifications those described by Baehner and Nathan [2]. Thirty milliliters of heparinized blood were obtained from each subject. Sedimentation was facilitated by adding sufficient $10 \%$ dextran in $0.15 \mathrm{~m} \mathrm{NaCl}$ to each specimen to obtain a final concentration of $1 \%$ dextran. Following removal of the leukocyte-rich plasma, 2 volumes of $0.87 \%$ ammonium chloride were added to the plasma to remove any residual erythrocytes. Centrifugation at $100 \times g$ was performed for 5-10 min. The supernatant was withdrawn and the cells were washed twice with Krebs-Henseleit-bicarbonate buffer, $\mathrm{pH} 7.4$, containing $200 \mathrm{mg} / 100 \mathrm{ml}$ of glucose. Differential counts of this fluid revealed values consistently in excess of $90 \%$ polymorphonuclear leukocytes.

Cell homogenates were prepared either from the frozen crude cell suspension or from fresh cells without freezing. Homogenization was accomplished either by repetitive freeze-thawing or by ultrasonication. Sonication was carried out at $4^{\circ}$ for $30 \mathrm{sec}$ employing a high intensity ultrasonic probe [23] using a frequency of $15 \mathrm{~K}$ cps. Immediately after cell disruption, the homogenates were centrifuged at $4^{\circ}$ for $15 \mathrm{~min}$ at $20,000 \times \mathrm{g}$ in an ultracentrifuge [24]. The supernatants were analyzed for protein content [14] and the enzymatic assays were performed as described below.
The activities of Glc-6 PD and of 6-phosphogluconic dehydrogenase (6-PGD) in red cell and white cell Iysates were determined [20]. The results of leukocyte enzyme activities were reported in international units (IU) as $\mu \mathrm{mole} / \mathrm{min} / \mathrm{g}$ of protein at $25^{\circ}$ and are expressed as percentage activity of that measured at time zero. Red cell Glc-6-PD activity was similarly determined on hemolysates of blood collected in acid citrate dextrose solution. Results were reported in international units as $\mu \mathrm{mole} / \mathrm{min} / \mathrm{g}$ hemoglobin at $25^{\circ}$ and are expressed as percentage activity of that measured at time zero. The optical densities were determined with a spectrophotometer [25] using 1-cm cuvettes that were maintained at $25^{\circ}$ by means of a circulating water bath.

Experiments were done to determine the effects of storage, stabilizing agents, and temperature on Glc-6PD activity. Leukocyte homogenates, prepared from leukocytes frozen at $-70^{\circ}$ in the presence of $10 \mu \mathrm{M}$ NADP, $14 \mathrm{~mm}$ 2-mercaptoethanol (2-ME), or $10 \mu \mathrm{M}$ NADP plus $14 \mathrm{~mm} 2-\mathrm{ME}$ were tested at 0,4 , and $18 \mathrm{~h}$ following storage at $4^{\circ}$. Comparable results were obtained when the various agents were added to fresh cells without prior freezing. Measurements of red cell activities were performed similarly. After preparation of red cell hemolysates, NADP or NADP and 2-ME were added to the hemolysates in tests of stability, as described above. Thermostability of Glc-6-PD was determined by heating the homogenates for $0,10,20$, and $30 \mathrm{~min}$ at $38^{\circ}$ prior to testing.

Electrophoretic mobility was determined in polyacrylamide gel using the method of GABrieL and WANG [9] and in starch gel (Tris $\mathrm{HCl}, \mathrm{pH} 8.8 \mathrm{buffer}$ ). Michaelis constants $\left(K_{m}\right)$ were determined for Glc-6PD using glucose 6-phosphate as substrate.

The quantitative nitroblue tetrazolium test (NBT) was performed by the method of BAEHNER and NATHAN [2], results being expressed as the change in optical density $(\triangle \mathrm{OD})$ between resting and phagocytosing values for $2.5 \times 10^{6} \mathrm{cells} / 15 \mathrm{~min}$ at $37^{\circ}$. The bactericidal assay was performed by the method of QurE et al. [17] using Staphylococcus aureus or Escherichia coli. The results were expressed as percentage reduction in viable bacteria after 120 min of incubation with polymorphonuclear leukocytes.

\section{Results}

All patients displayed an inability to reduce NBT dye and had impaired leukocyte bactericidal activity (table I). Preliminary testing revealed diminished leukocyte GIc-6-PD activity in all three patients when compared with age-related or adult control subjects.

Since there appeared to be wide fluctuations in the Glc-6-PD activity of leukocytes of patients from one 
determination to another suggesting enzyme lability, the effect of storage was next studied (table II). The rate of decay of leukocyte Glc-6-PD activity in each of the three patients exceeded that seen in cells from age-related and adult control subjects. Assays were also performed on homogenates of fresh unfrozen cells in patients $S E$ and $B P$. In both samples, a similar rapid decay was observed following storage. In all three patients, the red cell Glc-6-PD activities at zero time were similar to those of the controls (table II). By $18 \mathrm{~h}$, however, a more rapid rate of decay was observed in patients with GGD than in normal subjects.
The effects of stabilizing agents on leukocyte and erythrocyte Glc-6-PD activities are shown in table III. It may be seen that addition of $2-\mathrm{ME}$ or $2-\mathrm{ME}+$ NADP produced a stabilization effect in leukocyte homogenates from normal subjects as well as patients; however, the stabilizing effect was less marked in patients. A stabilizing effect of NADP was observed only in cells of control subjects and not in cells of patients with GGD. In erythrocytes from both patients and control subjects, stabilization of approximately the same degree was observed with NADP and 2-ME. The thermostability of leukocyte and erythrocyte Glc-

Table l. Laboratory findings in patients with chronic granulomatous disease and in normal subjects

\begin{tabular}{|c|c|c|c|c|c|}
\hline \multirow[t]{2}{*}{ Subjects } & \multirow{2}{*}{$\begin{array}{c}\text { Age, } \\
\text { yr }\end{array}$} & \multirow{2}{*}{$\begin{array}{c}\text { Bactericidal } \\
\text { activity }^{1} \\
\%\end{array}$} & \multirow[t]{2}{*}{$\mathrm{NBT}^{2}$} & \multicolumn{2}{|c|}{ Leukocyte } \\
\hline & & & & $\begin{array}{c}\text { Glc-6-PD } \\
\text { activity } \\
\mu \mathrm{mole} / \mathrm{m}\end{array}$ & $\begin{array}{l}\text { 6-PGD } \\
\text { activity } \\
\text { orotein }\end{array}$ \\
\hline \multicolumn{6}{|l|}{ Patients } \\
\hline$S E$ & 7 & 70 & 0.022 & 10 & 26 \\
\hline $\mathcal{F} M$ & 2.5 & 20 & 0.010 & 26 & 43 \\
\hline$B P$ & 4 & 60 & 0.015 & 11 & 49 \\
\hline \multicolumn{6}{|l|}{ Controls } \\
\hline$\kappa A$ & 7 & & 0.320 & 70 & 24 \\
\hline$\kappa B$ & 3 & $90-95$ & 0.125 & 100 & 42 \\
\hline$\kappa C$ & 13 & & 0.190 & 161 & 50 \\
\hline $\mathcal{F F}$ & 40 & & 0.250 & 100 & 36 \\
\hline
\end{tabular}

1 Bactericidal activity is expressed as the percentage reduction in viable bacteria after 120 min incubation with leukocytes.

${ }^{2}$ Nitroblue tetrazolium (NBT) results are expressed as $\triangle \mathrm{OD}$ at $515 \mathrm{~m} \mu / 2.5 \times 10^{6}$ leukocytes $/ 15 \mathrm{~min}$ at $37^{\circ}$.

Table II. Effect of storage at $4^{\circ}$ on activity of Glc-6-PD from leukocytes and erythrocytes

\begin{tabular}{|c|c|c|c|c|c|c|}
\hline \multirow[t]{2}{*}{ Subjects } & \multirow[t]{2}{*}{ Age, yr } & \multicolumn{3}{|c|}{ Leukocytes $^{1}, \%$} & \multicolumn{2}{|c|}{ Erythrocytes ${ }^{1}, \%$} \\
\hline & & $0 \mathrm{~h}$ & $4 \mathrm{~h}$ & $\overline{18 \mathrm{~h}}$ & $0 \mathrm{~h}$ & $18 \mathrm{~h}$ \\
\hline \multicolumn{7}{|l|}{ Patients } \\
\hline$S E$ & 7 & 100 & 42 & 0 & 100 & 58 \\
\hline$S E^{2}$ & & 100 & 74 & 0 & - & - \\
\hline$B P$ & 4 & 100 & 45 & 0 & 100 & 66 \\
\hline$B P^{2}$ & & 100 & 28 & 0 & - & - \\
\hline \multicolumn{7}{|l|}{ Controls } \\
\hline Adult & 30 & 100 & 95 & 58 & 100 & 93 \\
\hline Adult ${ }^{2}$ & 40 & 100 & 52 & 12 & 100 & 80 \\
\hline$P M$ & 7 & 100 & 86 & 71 & 100 & 100 \\
\hline
\end{tabular}

${ }^{1}$ Enzyme activities for leukocytes or erythrocytes expressed as percentage of activity measured at zero time.

${ }^{2}$ Enzyme activities on cell homogenates prepared immediately without prior freezing. 
6-PD at $38^{\circ}$ in two patients and a control is shown in table IV. A marked lability was observed in leukocytes and erythrocytes in each of the patients when compared with control values. The results of electrophoretic analyses and determination of Michaelis constant $\left(K_{m}\right)$ of leukocyte Glc-6-PD were essentially the same in patients and in controls.

The activity of a second NADP-dependent enzyme, 6-PGD, was studied in leukocyte homogenates. Results are presented in table $\Upsilon$. It can be seen that the activities in cells of patients were comparable to those in cells of age-related and adult controls.
The relation between the quantitative NBT test and Glc-6-PD activity is shown in figure 1. Data are included on infants and children of varying ages, as well as on patients with CGD and individuals of Negro and Middle Eastern origin. A linear correlation exists between the two variables with a correlation coefficient of $0.86, P<0.01$. The lower values for Glc-6-PD activity and NBT reduction were seen in newborn infants, younger children, a 4-month-old Negro male with the Glc-6-PD deficiency, and in the three patients with CGD. Preliminary studies indicate that there is an increase in GIc-6-PD activity and NBT reduction dur-

Table III. Effect of stabilizing agents on Glc-6-PD activities of leukocytes and erythrocytes

\begin{tabular}{|c|c|c|c|c|c|c|}
\hline \multirow[t]{2}{*}{ Subjects } & \multirow[t]{2}{*}{ Treatment } & \multicolumn{3}{|c|}{ Leukocytes $^{1}, \%$} & \multicolumn{2}{|c|}{ Erythrocytes $^{1}, \%$} \\
\hline & & $0 \mathrm{~h}$ & $4 \mathrm{~h}$ & $18 \mathrm{~h}$ & $0 \mathrm{~h}$ & $18 \mathrm{~h}$ \\
\hline \multicolumn{7}{|l|}{ Patients } \\
\hline \multirow[t]{4}{*}{$S E$} & 0 & 100 & 42 & 0 & 100 & 65 \\
\hline & NADP & 100 & 50 & 0 & 100 & 90 \\
\hline & 2-ME & 100 & 100 & 32 & - & - \\
\hline & $2-\mathrm{ME}+\mathrm{NADP}$ & 100 & 83 & 40 & 100 & 91 \\
\hline \multirow[t]{4}{*}{$B P$} & 0 & 100 & 45 & 0 & 100 & 66 \\
\hline & NADP & 100 & 53 & 0 & 100 & 100 \\
\hline & 2-ME & 100 & 80 & 36 & - & - \\
\hline & $2 \sim \mathrm{ME}+\mathrm{NADP}$ & 100 & 56 & 41 & 100 & 100 \\
\hline \multicolumn{7}{|l|}{ Controls } \\
\hline \multirow[t]{2}{*}{$P M$} & 0 & 100 & 86 & 71 & 100 & 100 \\
\hline & 2-ME+NADP & 100 & 100 & 82 & 100 & 100 \\
\hline Adults & 0 & 100 & 95 & 58 & 100 & 93 \\
\hline \multirow[t]{3}{*}{$(3)^{2}$} & NADP & 100 & 100 & 80 & 100 & 94 \\
\hline & 2-ME & 100 & 78 & 88 & - & - \\
\hline & 2-ME+NADP & 100 & 100 & 88 & 100 & 96 \\
\hline
\end{tabular}

1 Enzyme activities for leukocytes or erythrocytes expressed as percentage of activity measured at zero time.

2 Average values for three adults.

Table $I V$. Heat stability of leukocyte and erythrocyte Glc-6-PD activities at $38^{\circ}$

\begin{tabular}{|c|c|c|c|c|c|c|c|c|c|c|}
\hline \multirow[t]{3}{*}{ Subject } & \multirow{3}{*}{$\begin{array}{c}\text { Protein } \\
\text { conc, } \\
\mu \mathrm{g} / \mathrm{ml}\end{array}$} & \multicolumn{4}{|c|}{ Leukocyte $^{1}, \%$} & \multirow{3}{*}{$\begin{array}{l}\text { Hemo- } \\
\text { globin } \\
\text { conc, } \\
\mathrm{g} / 1,000 \mathrm{ml}\end{array}$} & \multicolumn{4}{|c|}{ Erythrocyte $^{1}, \%$} \\
\hline & & \multicolumn{4}{|c|}{ Min } & & \multicolumn{4}{|c|}{ Min } \\
\hline & & 0 & 10 & 20 & 30 & & 0 & 10 & 20 & 40 \\
\hline \multicolumn{11}{|l|}{ Patients } \\
\hline$S E$ & 880 & 100 & 40 & 17 & 0 & 11 & 100 & 100 & 87 & 67 \\
\hline$B P$ & 500 & 100 & 30 & 10 & 2 & 10.1 & 100 & 91 & 82 & 68 \\
\hline \multicolumn{11}{|l|}{ Control } \\
\hline \multirow[t]{2}{*}{$M M$} & 600 & 100 & 60 & 51 & 34 & 12 & 100 & 88 & 81 & 78 \\
\hline & 132 & 100 & 47 & 25 & 12 & & & & & \\
\hline
\end{tabular}

1 Enzyme activities for leukocytes or erythrocytes expressed as percentage of activity measured at zero time. 


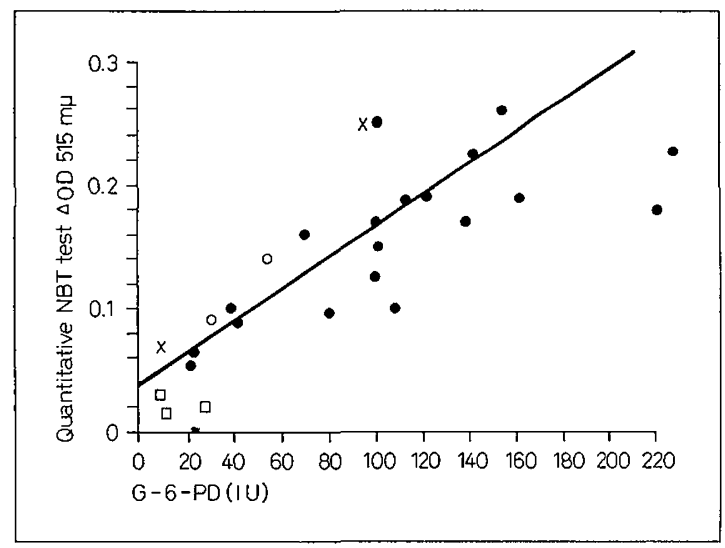

Fig.1. Correlation of leukocyte quantitative nitroblue tetrazolium test and glucose-6-phosphate dehydrogenase activity in cells from subjects of different ages. Correlation coefficient is $0.86, P<0.01 . \times:$ Negroes having the A-variant. $O$ : people of Mediterranean origin. $\square$ : patients with GGD. : normal subjects.

ing maturation [3]. Quantitative NBT dye reduction and Glc-6-PD decay curves were normal in control subjects during the course of viral and bacterial infections. Similar results were obtained in patients with CGD regardless of the presence or absence of infection. Homogenates from GGD leukocytes and normal leukocytes were mixed and Glc-6-PD decay curves obtained which were intermediate in their activities between those found in GGD and in normal controls.

\section{Discussion}

The results of the present studies reveal a more rapid rate of decrease in glucose 6-phosphate dehydrogenase (Glc-6-PD) activity in the leukocytes and erythrocytes of patients with GGD than in cells of normal subjects. Several hypotheses may be considered to explain these findings. The first is that there exists in CGD an increased activity of an enzyme degrading system or some other influence on a normal Glc-6-PD protein such as an inactivator or inhibitor. Leukocytes are known to possess relatively high concentrations of proteolytic substances that can affect Glc-6-PD activity [22]. The more rapid fall in Glc-6-PD activity during storage in leukocytes compared with the relatively slower rate in red cells is consonant with this view. Red cell activity, however, decreased more rapidly during storage and with heating in cells from patients with GGD than in those from normal subjects, sug- gesting that the enzyme itself might have been more vulnerable to normal degradative systems. The stabilization effect of 2-ME on the GIc-6-PD on cells from patients and from control subjects underscores the importance of maintaining critical sulfhydryl groups on the protein. It might be postulated, therefore, that the decay in activity reflects the effect of an oxidant, e.g., oxidized glutathione. Preliminary testing of glutathione reductase, however, has revealed no abnormalities.

Another explanation has been postulated by BAEHNER and KARNOvSKy [1]. These workers suggested that there might exist in CGD an inability to oxidize NADH, due to NADH oxidase deficiency. This would result in a relative failure to generate NADP, with a net decrease in turnover through the hexose monophosphate pathway during phagocytosis. This possibility, however, seems unlikely since it does not explain the augmentation of oxidation seen during phagocytosis in species lacking NADPH-linked lactate dehydrogenase [19]. KLEBANOFF and WhITE [12] recently have proposed still another basis for the defect in the disorder. These workers demonstrated an iodination defect in the leukocytes of patients with CGD and have shown a failure of such leukocytes to kill nonperoxideforming bacteria but a normal bactericidal effect with peroxide-forming bacteria. The relation of these findings to the defective phagocytosis may be related in some way to the defective HMP activity seen in this disorder.

Another hypothesis, that of a variant Glc-6-PD protein, appears to fit presently known characteristics of CGD. The mode of inheritance of most cases of CGD has been shown to be X-linked, corresponding with the established genetic locus for Glc-6-PD. The finding of diminished activity of enzyme in red cells and white cells of patients is consonant with this hypothesis. Further, the observation that NADP alone does not stabilize the Glc-6-PD enzyme activity of patients, may indicate an abnormal binding of NADP. An abnormality in Glc-6-PD activity would also explain the diminished ability in CGD of leukocytes to reduce NBT dye. We found a high degree of correlation between leukocyte NBT reduction and Glc-6-PD activity (fig. 1). Observations on this relation were expanded to include patients having other known red cell variants of Glc-6-PD and children of various ages. It has been previously shown that, in the red blood cell, NBT reduction is directly proportional to Glc-6-PD activity [8]. Indeed, Fairbanks and LAMPE [8] suggested that a red blood cell NBT screening test would be useful in diagnosis of primaquine-sensitive individuals having Glc-6-PD deficiency.

A number of physical and chemical techniques have been used to demonstrate red cell Glc-6-PD variants 
$[4,11]$. In the present study, an increased rate of decay was demonstrated in leukocytes and erythrocytes of all three CGD patients by performing Glc-6-PD assays at timed intervals on stored and fresh specimens and under the influence of stabilizing agents and heating at $38^{\circ}$. Although the observed data are compatible with the presence of a variant Glc-6-PD in this disorder, the possibility of an inhibitor within the leukocytes of these patients has not been excluded.

Previous studies on the functional consequences of Glc-6-PD variants have focused on alterations in red cell metabolism manifested by hemolysis. The findings in the present study appear to have uncovered a new derangement resulting in a functional impairment of white cell metabolism manifested by impaired phagocytosis. Previously described Glc-6-PD variants have not been associated with known derangement of leukocyte function, even in those instances in which there is a known decrease in white cell Glc-6-PD activity such as in the Mediterranean variant $[15,18]$.

The disease has recently been described in females, suggesting the possibility of genetic heterogeneity for the entity with some cases resulting from an autosomal mutant gene $[2,7,16]$. The pedigree data and phenotypic expression in females are also compatible with variable degrees of expression by an X-linked gene due to incomplete dosage compensation [21]. Although this issue is unresolved at present it is likely that a number of different genetic mutations and molecular disorders of metabolism will be found to underly the clinical entity now recognized as CGD [7].

\section{Summary}

Three male infants with the classic form of chronic granulomatous disease (GGD) were studied. An accelerated decay of glucose 6-phosphate dehydrogenase (Glc-6-PD) activity was found in homogenates of leukocytes and red cells from these patients. These findings suggest the presence of a variant Glc-6-PD enzyme or an enhanced degradation of a normal enzyme in the disorder. These changes were correlated with decreased ability to reduce NBT dye (quantitative nitroblue tetrazolium test) known to occur in CGD.

\section{References and Notes}

1. Baehner, R. L. and Karnovsky, M. L. : Deficiency of reduced nicotinamide-adenine dinucleotide oxidase in chronic granulomatous disease. Science 162 : 1277 (1968).

2. Baehner, R.L. and Nathan, D.G.: Quantitative nitroblue tetrazolium test in chronic granulomatous disease. New Engl.J. Med. 278: 971 (1968).

3. Bellanti, J.A.; Cantz, B. E.; Maybee, D. A. and SCHLEGeL, R.J.: Defective phagocytosis by newborn leukocytes: A defect similar to that in chronic granulomatous disease (Abstract). Pediat. Res. 3: 376 (1969).

4. Beutler, E.: Drug-induced hemolytic anemia. Pharmacol. Rev. 21: 73 (1969).

5. Bridges, R.A.; Berendes, H. and Good, R.A.: A fatal granulomatous disease of childhood: The clinical, pathological, and laboratory features of a new syndrome. Amer. J. Dis. Child. 97: 387 (1959).

6. Carson, M.J.; Ghadwick, D.L. and Brubaker, C.A.: Thirteen boys with progressive septic granulomatosis. Pediatrics 35: 405 (1965).

7. Douglas, S.D.; Davis, W.C. and FudenberG, H.H.: Granulocytopathies: pleomorphism of neutrophil dysfunction. Amer. J. Med. 46: 901 (1969).

8. Fairbanks, V.F. and Lampe, L.T.: A tetrazoliumlinked cytochemical method for estimation of glucose-6-phosphate dehydrogenase activity in individual erythrocytes: Applications in the study of heterozygotes for glucose-6-phosphate dehydrogenase deficiency. Blood 31: 589 (1968).

9. Gabriel, O. and WAng, S.F.: Determination of enzymatic activity in polyacrylamide gels. I. Enzymes catalyzing conversion of non-reducing substrates to reducing products. Analyt. Biochem. 27: 545 (1969).

10. Holmes, B.; Page, A.R. and Good, R.A.: Studies of the metabolic activity of leukocytes from patients with a genetic abnormality of phagocytic function. J. clin. Invest. 46: 1422 (1967).

11. Kirkman, H.N.; McGurdy, P.R. and Naiman, J.L.: Functionally abnormal glucose-6-phosphate dehydrogenases. Cold Spr. Harb. Symp. quant. Biol. 19: 391 (1964).

12. Klebanoff, S.J. and White, L.R.: Iodination defect in leukocytes of patients with chronic granulomatous disease of childhood. New Engl.J. Med. 280: 460 (1969).

13. Landing, B.H. and Shrrkey, H.S.: A syndrome of recurrent infection and infiltration of viscera by pigmented lipid histiocytes. Pediatrics 20: 431 (1957).

14. Lowry, O.H.; Rosebrough, N.J.; Farr, A.L. and RANDALL, R.J.: Protein measurement with the Folin phenol reagent. J.biol. Chem. 193: 265 (1951).

15. Marks, P.A. and Gross, R.T.: Erythrocyte glucose-6-phosphate dehydrogenase deficiency: Evidence of differences between negroes and caucasians with respect to this genetically determined trait. J.clin. Invest. 38: 2253 (1959). 
16. Quie, P.G.; Kaplan, E.L.; Page, A.R.; GrusKaY, F.L. and Malawista, S.E.: Defective polymorphonuclear-leukocyte function and chronic granulomatous disease in two female children. New Engl.J. Med. 278: 976 (1968).

17. Quie, P.G.; White, J.G. and Holmes, B.: In vitro bactericidal capacity of human polymorphonuclear leukocytes: Diminished activity in chronic granulomatous disease of childhood. J.clin. Invest. 46: 668 (1967).

18. Ramot, B.; Frsher, S.; Szernberg, A.; AdAm, A.; Sheba, C. and Gafni, D.: A study of subjects with erythrocyte glucose-6-phosphate dehydrogenase deficiency. II. Investigation of leukocyte enzymes. J. clin. Invest. 38: 2234 (1959).

19. Reed, P.W.: Glutathione and the hexose monophosphate shunt in phagocytosing and hydrogen peroxide-treated rat leukocytes. J. biol. Chem. 244: 2459 (1969).

20. Richterich, R.: Clinical chemistry, theory and practice (S. Karger, Basel/München/New York 1969).

21. Windhorst, D.B.; Page, A.R.; Holmes, B.; QUIE, P.G. and Good, R.A.: The pattern of genetic transmission of the leukocyte defect in fatal granulomatous disease of childhood. J. clin. Invest. 47: 1026 (1968).

22. Yoshida, A.; Stamatoyannopoulos, G. and MoTULSKY, A. G.: Biochemical genetics of glucose-6phosphate dehydrogenase variation. Ann. N.Y. Acad. Sci. 155: 868 (1968).

23. Biosonik II, Bronwill Scientific, Rochester, NY.

24. Model L2, Beckman Instruments, Inc., Spinco Division, Palo Alto, GA.

25. Beckman DU-Gilford, Beckman Instruments, Inc., Fullerton, CA.

26. Informed consent was obtained for all subjects in this study.

27. We thank Drs. Othmar Gabriel and Paul MCCURDY for their many helpful suggestions and for their assistance in the electrophoretic studies.

28. Supported by U.S. Army Medical Research and Development Command Research Contract no. DA-49-193-MD-2633.

29. Requests for reprints should be addressed to JoSEPH A.Bellanti, M.D., Georgetown University School of Medicine, 3800 Reservoir Road, N.W., Washington, DC 20007.

30. Accepted for publication December 31, 1969. 